\title{
Technical/Administrative Options for Managing Tritium MCL Exceedances in P-Area Groundwater and Steel Creek
}

ERD-EN-2017-0034

Revision 0 


\section{DISCLAIMER}

This document was prepared in conjunction with work accomplished under Contract No. DE-AC09-08SR22470 with the U.S. Department of Energy.

This work was prepared under an agreement with and funded by the U.S. Government. Neither the U.S. Government or its employees, nor any of its contractors, subcontractors or their employees, makes any express or implied: 1. warranty or assumes any legal liability for the accuracy, completeness, or for the use or results of such use of any information, product, or process disclosed; or 2. representation that such use or results of such use would not infringe privately owned rights; or 3 . endorsement or recommendation of any specifically identified commercial product, process, or service. Any views and opinions of authors expressed in this work do not necessarily state or reflect those of the United States Government, or its contractors, or subcontractors.

\begin{tabular}{|c|}
\hline Printed in the United States of America \\
Prepared for \\
U.S. Department of Energy \\
and \\
Savannah River Nuclear Solutions, LLC \\
Aiken, South Carolina
\end{tabular}


$\underline{\text { Section }}$

\section{TABLE OF CONTENTS}

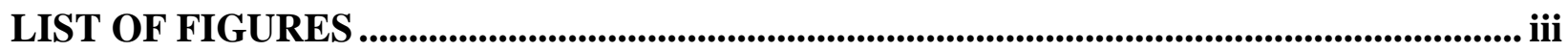

LIST OF ABBREVIATIONS AND ACROYNMS ........................................................................v

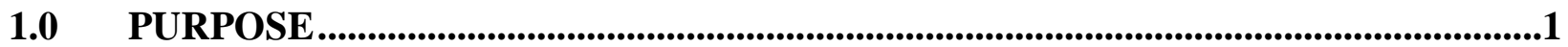

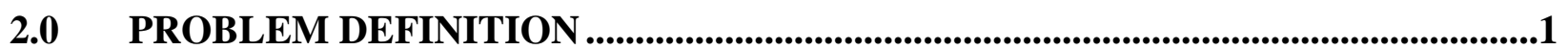

3.0 OTHER RELATED OPERABLE UNITS AND DECISIONS .....................................2

4.0 TECHNICAL APPROACH.........................................................................................

4.1 Phytoirrigation using Collection Pond...................................................................................

4.2 Phytoirrigation using Recovery Wells ..............................................................................4

4.3 Tank Storage or Forced Evaporation ...................................................................................

4.4 Engineered Subsurface Barrier .........................................................................................4

4.5 Natural Attenuation with Land Use Controls (LUCs) and Monitoring ......................5

5.0 OPERABLE UNIT AND ADMINISTRATIVE CONSIDERATIONS .........................6

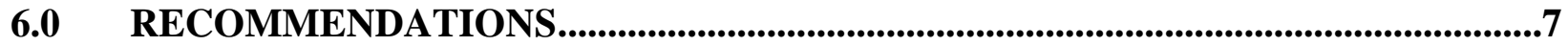

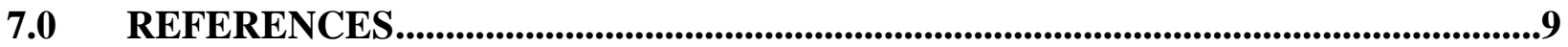

Figure Page

Figure 1. Tritium Groundwater Plume in the UAZ.......................................................11

Figure 2. Tritium Groundwater Plume in the LAZ .............................................................13

Figure 3. Cross Section B-B' of Tritium Groundwater Plume from East of $\mathbf{P}$ Area West towards Steel Creek ...................................................................................15

Figure 4. PAGW and LASG Tritium Plumes and Steel Creek Surface Water Concentrations ...............................................................................................................17

Figure 5. Time versus Concentration Plot for Tritium in Surface Water .........................19

Figure 6. Steel Creek Surface Water Collection Pond and Watersheds...........................20

Figure 7. Phytoirrigation from Collection Pond Average Annual Water

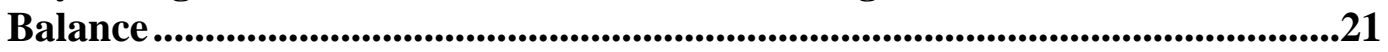


This page intentionally left blank. 


\section{LIST OF ABBREVIATIONS AND ACROYNMS}

$\sim$

ac

CERCLA

CMS/FS

ESB

$\mathrm{ft}$

FS

gal

GAU

gpm

in.

IOU

LASG

LAZ

LUCs

$\mathrm{m}$

MCL

MNA

MWMF

NEPA

NPDES

OU

$\mathrm{pCi} / \mathrm{mL}$

PR

RAOU

ROD

SCDHEC

SRNS

SRS

TI

USDOE

UAZ

USEPA

VOCs approximate, approximately

acre

Comprehensive Environmental Response, Compensation and Liability Act Corrective Measures Study/Feasibility Study

engineered subsurface barrier

feet

Feasibility Study

gallon

Gordon Aquifer Unit

gallons per minute

inch

Integrator Operable Unit

L-Area Southern Groundwater

Lower Aquifer Zone

land use controls

meter

maximum contaminant level

Monitored Natural Attenuation

Mixed Waste Management Facility

National Environmental Policy Act

National Pollutant Discharge Elimination System

Operable Unit

picocurie per milliliter

Periodic Report

R-Area Operable Unit

Record of Decision

South Carolina Department of Health and Environmental Control

Savannah River Nuclear Solutions

Savannah River Site

Technical Impracticability

United States Department of Energy

Upper Aquifer Zone

United States Environmental Protection Agency

volatile organic compounds 
This page intentionally left blank. 


\subsection{PURPOSE}

This white paper was requested by the Core Team (United States Department of Energy [USDOE], United States Environmental Protection Agency [USEPA], and South Carolina Department of Health and Environmental Control [SCDHEC]) at the P-Area Groundwater (PAGW) Operable Unit (OU) Scoping Meeting held in January 2017 to discuss recent data and potential alternatives in support of a focused Corrective Measures Study/Feasibility Study (CMS/FS). This white paper presents an overview of the problem, and a range of technical and administrative options for addressing the tritium contamination in groundwater and Steel Creek.

As tritium cannot be treated practicably, alternatives are limited to media transfer, containment and natural attenuation principally relying on radioactive decay. Using other groundwater OU decisions involving tritium as precedent, Savannah River Nuclear Solutions (SRNS) recommends that final tritium alternatives be evaluated in a CMS/FS, understanding that the likely preferred remedy will include natural attenuation with land use controls (LUCs). This is based on the inability to significantly reduce tritium impact to Steel Creek using an engineered solution as compared to natural attenuation. The timing of this evaluation could be conducted concurrently with the final remedy evaluation for volatile organic compounds (VOCs).

\subsection{PROBLEM DEFINITION}

Tritium (H-3) is present in groundwater at Savannah River Site (SRS) primarily due to historical operational discharge of cooling water or spills and leaks of tritiated process water. Tritium has a half-life for radioactive decay of 12.3 years, and disintegrates into stable helium by beta particle emission. Tritiated water is assumed to behave the same as water, with no sorption to aquifer solids (USEPA 2010). However, empirical data indicates that there appears to be a significant transport lag of a portion of the tritiated water, as compared to transport model results using a $\mathrm{Kd}$ of 0 , which may be related to complex flow paths in heterogeneous aquifer/aquitard materials, whereas, modeled hydrogeological systems are typically homogeneous by necessity.

\section{Nature and Extent}

Tritiated water discharges and releases from P Reactor facilities have resulted in both groundwater and surface water (Steel Creek) exceeding the $20 \mathrm{pCi} / \mathrm{mL}$ maximum contaminant level (MCL) for tritium. Remedial action objectives include reducing groundwater and surface water concentrations to below the MCL, reducing discharge of tritium contaminated groundwater to surface water, and preventing human exposure to tritium above MCLs.

The depth to groundwater in P Area is about 45 to 50 feet (ft). P Area is on a groundwater divide, with flow to both the west towards Steel Creek and east towards PAR Pond. The uppermost aquifer (Upper Three Runs) generally consists of a series of higher and lower permeability zones, from top down referred to as the Upper Aquifer Zone (UAZ), Tan Clay, upper Lower Aquifer Zone (LAZ), middle clay of the LAZ, and lower LAZ. The total thickness of these units is about $150 \mathrm{ft}$. Below the Upper Three Runs aquifer is the Gordon Confining Unit, underlain by the Gordon Aquifer. Tritium MCL exceedances in groundwater occur in an area of about 96/78 acres (ac) in the UAZ/LAZ. Significant areas ( 20 ac in 
both the UAZ and LAZ) are estimated to exceed 1,000 pCi/mL. Except to the northwest of the seepage basins, tritium contamination is limited to the upper $100 \mathrm{ft}$ of the aquifer. Only one well in the Gordon Aquifer is contaminated, which is adjacent to and north of Seepage Basin 2. Figures 1 and 2 show the extent of tritium contamination in the UAZ and LAZ, respectively. Figure 3 is a cross-section showing the hydrogeologic units and approximate extent of contamination vertically. The sources of tritium have been remediated, as described by the Records of Decision (ROD) for the P-Area Reactor Seepage Basins (WSRC 2000) and the P-Area Operable Unit (SRNS 2010).

The upper portion of Steel Creek, from nearly the head waters in P Area to L-Lake, covering a distance of about 12,000 linear ft, exceeds the MCL for tritium in surface water. This section of Steel Creek was significantly impacted by high-flow discharge from the reactor; erosion has resulted in the development of a "canyon" with steep relief. The highest concentrations are consistently observed at sampling location SC-03, and are currently $\sim 600 \mathrm{pCi} / \mathrm{mL}$. Tritium concentrations are currently $\sim 20 \mathrm{pCi} / \mathrm{mL}$ just above L-Lake. Figure 4 shows the extent of tritium contamination from Steel Creek downstream to L-Lake, extending to below the dam.

\section{Fate and transport}

Almost all of the tritium contamination in the UAZ and LAZ, which was sourced from the seepage basins and northern portion of the reactor area, is flowing towards Steel Creek. Results from monitoring wells indicate decreasing tritium concentrations, as do measurements of tritium in Steel Creek since 2002, which indicate that tritium levels have decreased by over 50\% since 2007 (Figure 5). The trend data also indicate that the bulk of tritium discharge occurs between locations SC-02 and SC-03.

The updated PAGW baseline modeling report (SRNS 2015) indicates tritium discharge at levels exceeding MCLs estimated to occur at SC-03 for approximately 30 yrs. The predicted surface water concentration at SC-04 exceeds the MCL for less than 20 years. However, the base case model assumes advective transport of groundwater with no retardation of tritium. This may not be conservative based on empirical data, which has shown about a 50\% reduction over the last 10 to 15 years. Assuming reductions based on the half-life of tritium, concentrations at SC-03 would remain above the MCL for about 70 years, which represents an upper bound. Although tritium concentrations are predicted to remain above MCLs in the LAZ for 100 years, no breakthrough of tritium to the Gordon Aquifer Unit (GAU) occurs over the modeled time period. The model predicts that tritium will not impact any other surface water bodies in the vicinity of P Area within the modeled duration, including PAR Pond and the canals and tributaries of PAR Pond. The plume is predicted to move past SC-04 in the upper LAZ towards L-Lake, but degrades based on tritium decay and does not reach L-Lake during the entire 100-year simulation.

\subsection{OTHER RELATED OPERABLE UNITS AND DECISIONS}

Discharges from the operation of P and L Reactors in the 1950s - 1960s resulted in the radionuclide contamination of Steel Creek floodplain sediments, primarily with cesium-137. These sediments were submerged by the creation of L-Lake in 1985, to support L-Reactor restart. With the permanent shutdown of L Reactor, discontinuation of the SRS river water distribution system was considered. In an National Environmental Policy Act (NEPA) ROD signed in January of 1998, No Action was selected; requiring USDOE to continue operation of the river water system to maintain the water level of L-Lake at a level of 
190-ft mean sea level. The decision was made largely based on the expectation that complete characterization of L-Lake sediments would lead to a planned Comprehensive Environmental Response, Compensation and Liability Act (CERCLA) interim ROD in 2001. However, L-Lake was subsequently integrated into the Steel Creek Integrator Operable Unit (IOU) and the current Federal Facility Agreement has a Phase III field start of 2034. The NEPA ROD stated that in the absence of the lake water, exposure to lake bed contaminants (Cs-137) was unlikely to pose a significant risk to the SRS worker, based on an annual dose of $41 \mathrm{mrem}$ as compared to the USDOE administrative annual limit of 700 mrem. However, this dose equates to a risk ( 8E-04) that is greater than USEPA's acceptable risk range.

The Steel Creek IOU consists of the surface water and floodplain soil/sediment associated with all surface water features in the Steel Creek watershed. The program also looks at the potential sources contributing contamination to the IOU from within the watershed boundaries, thus both PAGW and L-Area Southern Groundwater (LASG) are recognized. The cesium-137 levels in upper Steel Creek sediments exceed the human health benchmark and require administrative control (radiological postings) identified in Steel Creek IOU Periodic Report (PR) \#3 (2007) to limit exposure. The most recent PR was in June 2014.

A final remedy decision for LASG was reached in 2007; Monitored Natural Attenuation (MNA) with Institutional Controls was selected. The National USEPA Review Board recommended that MNA for tritium be included and evaluated as part of the CMS/FS. Contaminants above MCLs included trichloroethylene, tetrachloroethylene and tritium. The groundwater plumes are discharging into L-Lake. The estimated time for tritium to decay below its MCL is 50 years. All historical tritium concentrations below L-Lake dam in Steel Creek (location SC-27 on Figure 4) have been less than the MCL and are continuing to decline. Surface water concentrations in L-Lake have been less than MCL since 2012.

\subsection{TECHNICAL APPROACH}

\section{$\underline{\text { Tritium Treatment and Management }}$}

Tritium differs from other contaminants in that no treatment technology exists that is practicable to remove tritium from large volumes of groundwater. SRS provides SCDHEC with a report every five years in accordance with the Resource Conservation and Recovery Act Permit for the Mixed Waste Management Facility (MWMF) Hazardous Waste Management Facilities, which examines tritium technologies and documents whether any new tritium treatment have emerged. SRS has used media transfer (water to vapor) as a way to manage tritium contaminated water, using evaporators to address tritiated disassembly basin water, and phytoirrigation of groundwater at the MWMF.

\subsection{Phytoirrigation using Collection Pond}

A PAGW groundwater model and report (SRNS 2011) provided transport predictions and evaluated the impacts of various remediation alternatives. Alternative 2 consisted of a dammed pond on Steel Creek with phytoirrigation. The pond is located about halfway between upper Steel Creek sampling locations SC-03 and SC-04, downstream of known tritiated groundwater discharge. Water is collected in the pond and pumped to irrigate about 8 ac (using the footprint of the 904-86G Retention Basin, which lies over the plume). Additional spraying in pond is proposed to promote evaporation. The alternative configuration is shown on Figure 6. Water balance calculations demonstrate that annual average overflow from the pond will be significant as shown in Figure 7. Pond overflow is over double that lost through 
phytoirrigation and evaporation. Irrigation plot size would have to be increased to over 100 ac to prevent pond overflow. However, this assumes tritium loss through irrigation is steady over entire year, which is an unreasonable assumption given significant decrease in evapotranspiration rates in fall/winter. An additional concern with a 100+ ac plot size would involve irrigation over clean areas of the aquifer, which would require careful regulation of the water application rates in fall/winter to prevent infiltration of tritiated water. Thus, the goal of reaching the tritium MCL in Steel Creek does not appear to be technically achievable.

\subsection{Phytoirrigation using Recovery Wells}

Another potential alternative to capture tritium in a targeted fashion would be a series of recovery wells. In theory this would be attractive since unlike a pond, limited "clean" water would be captured. However, given current concentrations of $600 \mathrm{pCi} / \mathrm{mL}$ at location SC-03 in Steel Creek, greater than 95\% reduction in the tritium flux would be required to meet MCLs. Given the current extent of the plume in the UAZ and LAZ, developing an adequate design to capture such a high percentage would likely not be achievable. As with the pond concept, similar water management issues exist. Phyto-irrigating only the 8 acres in the retention basin would limit the recovery rates from the wells to less than 6 gallons per minute (gpm). This recovery rate is probably inadequate given the estimated groundwater recharge to the upper portion of Steel Creek is about $90 \mathrm{gpm}$. Increasing the recovery/application rate to allow infiltration and subsequent recapture poses a problem because the uppermost portion of the UAZ is below MCLs, and would become contaminated by infiltration of the tritiated water, thus requiring recovery from a larger vertical portion of the aquifer. Since only a limited portion of the captured water is removed from the system by evapotranspiration, hydraulic control of the plume would quickly become impossible as tritiated water would bypass the recovery wells. Even large recovery systems ( 500 gpm from 12 recovery wells in A/M Area) with $100 \%$ water removal have demonstrated that over time plume containment is challenging. Thus, although a potential improvement over the pond, it is highly likely that after a short period of reduced concentrations, discharge of tritium contaminated water to Steel Creek would resume and the MCL could not be achieved.

\subsection{Tank Storage or Forced Evaporation}

Two possible solutions to the water management problem posed above include storage of the tritiated water in tanks or forced evaporation. Assuming that $20 \%$ of the groundwater discharge would require capture, 8 million (M) gallons (gal) per year (at $15 \mathrm{gpm}$ ) would need to be stored. The creation of such a large tank farm designed to store water for approximately over 50 years is not feasible. Alternatively, forced evaporation using diesel fired evaporators has been used at SRS to manage tritium at the disassembly basins, although not for such an extended period of time or large volume of water. In order to treat about 3,800 gal per hour (8 $\mathrm{M}$ gal over 40 hours per week) thirty of the evaporators used in $\mathrm{C}$ Area would be needed. A facility to house the evaporators would have to be constructed, and based on the C Area project, up to 120,000 gal of diesel fuel storage would be needed. Also considering the incurred cost of nearly $\$ 25 \mathrm{M}$ for $\mathrm{C}$ Area, the scale up required for this approach is not reasonable.

\subsection{Engineered Subsurface Barrier}

Another approach to managing discharge of tritium contaminated groundwater to Steel Creek would be through the construction of an engineered subsurface barrier (ESB) along Steel Creek, thereby, directly reducing discharge of contaminated groundwater to Steel Creek and accounting for increased travel time 
in the subsurface to allow for adequate decay time to occur where concentrations would be below the MCL before reaching the creek. The ESB would need to extend from the UAZ and into the LAZ to a depth of at least 145-ft below land surface to "capture" the tritium and would need to be of sufficient length (estimated to exceed 3,000 linear ft). However, a concern would be the resulting buildup of hydraulic head along the wall that could increase vertical migration of tritiated groundwater into deeper aquifer units (e.g., bottom of the LAZ or GAU). Current downward head differences range from 10 to 35 $\mathrm{ft}$ in the area of the tritium plume. In order to answer this question, detailed modeling of this alternative would be required. Further, significant additional investigation would be required to determine whether a continuous confining unit was present, which would be needed to key the base of the ESB into.

\subsection{Natural Attenuation with Land Use Controls (LUCs) and Monitoring}

Since the tritium plume is attenuating based on a radioactive half-life of 12.3 years, acknowledging this mechanism as a remedy component is logical. Source controls limiting tritium mobility were implemented as part of final decisions for both the P-Area Seepage Basins and P-Area Operable Unit (WSRC 2003, SRNS 2010). The radioactive decay of tritium in the plume results in decreasing plume mass and concentration over time. Empirical data from Steel Creek and the monitoring wells demonstrate decreasing tritium trends.

At LASG, natural attenuation processes (radioactive decay and dispersion) that are part of the approved remedy have been demonstrated to remain effective over time in reducing tritium to concentrations below the MCL below the L-Lake dam ensuring for the protectiveness of potential downgradient receptors in Steel Creek. MNA was approved for LASG given that some locations in L-Lake were known to exceed the MCL. Currently at PAGW, the entire section of Steel Creek above L-Lake and some spatial plume growth (area $>$ MCL) is expected in the future. Therefore, if these criteria make it difficult to approve "MNA" as a remedy, alternative language such as "natural attenuation with monitoring" or "LUCs with monitoring”, should be considered.

Exposure to tritiated water is currently managed at SRS through administrative controls or LUCs. Tritium levels in the Savannah River are well below drinking water standards, and reductions in permitted SRS discharges and radioactive decay of tritium in the groundwater plumes result in the ongoing decline of tritium levels in the Savannah River. (EMS ref) On site creeks that exceed the MCL are controlled to prevent unacceptable exposure. Specifically at PAGW, LUCs would be required to prevent use of contaminated groundwater or surface water. Given that the entire reach of Steel Creek up to L-Lake is currently above MCLs, L-Lake could be required to be maintained at full pool to keep tritium levels below MCL beyond the current headwaters.

In summary, all remedial approaches for addressing tritium rely significantly on hydraulic capture or control, in that no treatment technology exists that is practicable to remove tritium from large volumes of groundwater. Given a remedial goal that is currently 30 times less than current surface water tritium concentrations, the complex hydrogeology at PAGW, and the extensive groundwater plume that exists in two aquifer zones, achieving this goal will be very difficult at best, if not impossible from an engineering standpoint. Natural attenuation and LUCs with monitoring provides a viable remedial path to achieving remedial goals in groundwater and surface water, in 100 and 50 years, respectively. 


\section{Regulatory Approach or Documentation of Technical Analysis}

There are two general options for administratively capturing this argument: 1) a standard comparative analysis in a Feasibility Study (FS), or 2) a demonstration to receive a Technical Impracticability (TI) waiver.

The use of an FS at SRS has precedent for a number of MNA remedy decisions. These include OUs with long time frames to reach MCLs in groundwater; such as R-Area Operable Unit (RAOU) with estimates of up to 125 years to reach MCLs for VOCs and tritium, and RSB with estimates of over 300 years to reach the MCL for Sr-90. At LASG, modeling predicted tritium discharges to L-Lake exceeding the MCL for up to 50 years, although the empirical data indicates that this timeframe is likely overestimated. For each of these remedies the expectation that LUCs will remain viable into the future was key.

At RAOU, two alternatives were evaluated, no action and LUCs with MNA for groundwater. At RSB, alternative options focused on the contamination in the seepage basins and surrounding soils/pipelines. A mixing zone for groundwater was included as a component of each alternative. No active treatment alternatives for tritium were evaluated. For LASG, two plumes were examined, the western tritium only plume and an eastern commingled VOC and tritium plume. Alternatives to address tritium included no action, MNA with institutional controls, and spray irrigation/phytoremediation with monitoring and institutional controls.

TI waivers are one of the means of waiving applicable or relevant and appropriate requirements, consistent with CERCLA and the National Contingency Plan. USEPA published initial guidance on TI waivers in "Guidelines for Evaluating the Technical Impracticability of Ground Water Restoration", Office of Solid Waste and Emergency Response Directive 9234.2-25, September 1993. More recently in August 2012, USEPA published "Summary of Technical Impracticability Waivers at National Priority List Sites”, which categorized the 91 TI waivers issued to date. As of 2012, none of the waivers were specifically for tritium. The TI waivers were coupled with institutional controls at 69 of the sites, and with MNA at 17 of the sites.

In December of 2016 USEPA published OLEM Directive 9200.3-117, "Clarification of the Consultation Process for Evaluating the Technical Impracticability of Groundwater Restoration at CERCLA Sites”. The directive recommends a structured process for TI evaluations that includes involvement of USEPA OLEM in the planning and review process, and an extensive summary checklist for the evaluation of the demonstration.

Given the established CERCLA documentation path at SRS for groundwater remedies to date involving MNA, the use of an FS to provide the comparative analysis needed to propose and select a remedy consisting of natural attenuation, LUCs, and monitoring is appropriate.

\subsection{OPERABLE UNIT AND ADMINISTRATIVE CONSIDERATIONS}

The PAGW OU currently includes the contaminated groundwater and surface water as subunits. This follows the model for other groundwater OUs (e.g. LASG and C-Area Groundwater) where impacted surface water is included since it is the direct result of groundwater discharge. The definition of the OU boundary and ultimately the LUC boundary may merit some consideration due to the large extent that 
they may encompass. For PAGW, the OU boundary closely approximates the boundaries used in the groundwater model. It extends from PAR Pond (east) to upper Steel Creek nearly the headwaters of L-Lake to the west and to Myers Branch to the southwest. In the future, the LUC boundary would be reduced spatially around P Area, as only the groundwater plumes would require control. In addition, the upper Steel Creek and the floodplain (which would include monitoring wellpoints) would be included, as well as L-Lake until headwater samples no longer exceeded MCLs. The surface water sampling location downstream of L-Lake (SC 27), as measured below the L-Lake dam and used as the LSoGW "compliance point”, could also be used for PAGW. Based on current trends, tritium concentrations are likely to decrease to below the MCL at the head of the lake within 10 years.

The upper portion of Steel Creek and L-Lake are part of the Steel Creek IOU. As previously mentioned, administrative controls (rad postings) were required as part of the PR\#3 due to cesium-137 in the sediments of upper Steel Creek. However, since tritium levels in surface water did not exceed an IOU early action benchmark, no action under the IOU program has been considered for tritium. Given the final ROD date of 2039, using the IOU administrative vehicle for a decision on tritium in surface water does not seem timely. Further, although the IOU program considers watershed sources (such as groundwater) in its evaluation of the streams, a decision for groundwater has never been made as part of an IOU decision.

\subsection{RECOMMENDATIONS}

The existing CERCLA remedial process for the PAGW OU provides an appropriate path to reach a final decision for tritium groundwater contamination. A feasibility study that provides a comparative analysis of remedial alternatives including no action, "natural attenuation, LUCs and monitoring", and tritium discharge management and media transfer (water to air) options would provide the basis for remedy selection. An updated groundwater model would be used as a tool to compare the alternatives effectiveness. Assuming modeling results that demonstrate that MCLs in upper Steel Creek could not be reasonably achieved, the expected outcome would result in a "natural attenuation, LUCs and monitoring" remedy selection. The length of time LUCs would be required for the distinct media (L-Lake, upper Steel Creek, and groundwater) would be based on monitoring results.

The timing of this final remedial decision for tritium should be paired with the final remedial decision for VOCs. 
This page intentionally left blank. 


\subsection{REFERENCES}

SRNS, 2010. Record of Decision Remedial Action Selection for the P-Area Operable Unit (PAOU) (U), SRNS-RP-2009-01368, Savannah River Nuclear Solutions LLC, Aiken, SC. April 2010

SRNS, 2011. Groundwater Modeling and Alternatives Assessment for the P-Area Reactor Groundwater Operable Unit (U), SRNS-RP-2010-01746, Savannah River Nuclear Solutions LLC, March 2011, Aiken, SC

SRNS, 2015. Baseline Groundwater Model Update for P-Area Reactor Groundwater Operable Unit (U), NBN, SRNS-RP-2015-00768, Savannah River Nuclear Solutions LLC, September 2015, Aiken, SC

USEPA, 2010. Monitored Natural Attenuation of Inorganic Contaminants in Ground Water, Volume 3 - Assessment for Radionuclides Including Tritium, Radon, Strontium, Technetium, Uranium, Iodine, Radium, Thorium, Cesium, and Plutonium-Americium, National Risk Management Research Laboratory, Office of Research and Development, U.S Environmental Protection Agency, EPA/600/R-10/093, September 2010, Cincinnati, OH 45268

WSRC, 2000.

WSRC, 2003. Explanation of Significant Difference (ESD) for the Plug-In ROD for In Situ Stabilization with a Low Permeability Soil Cover System for Radiological Contaminants in Soil - P-Area Reactor Seepage Basins (U), WSRC-RP-2002-4105, Westinghouse Savannah River Company LLC, June 2003, Aiken, SC 
This page intentionally left blank. 


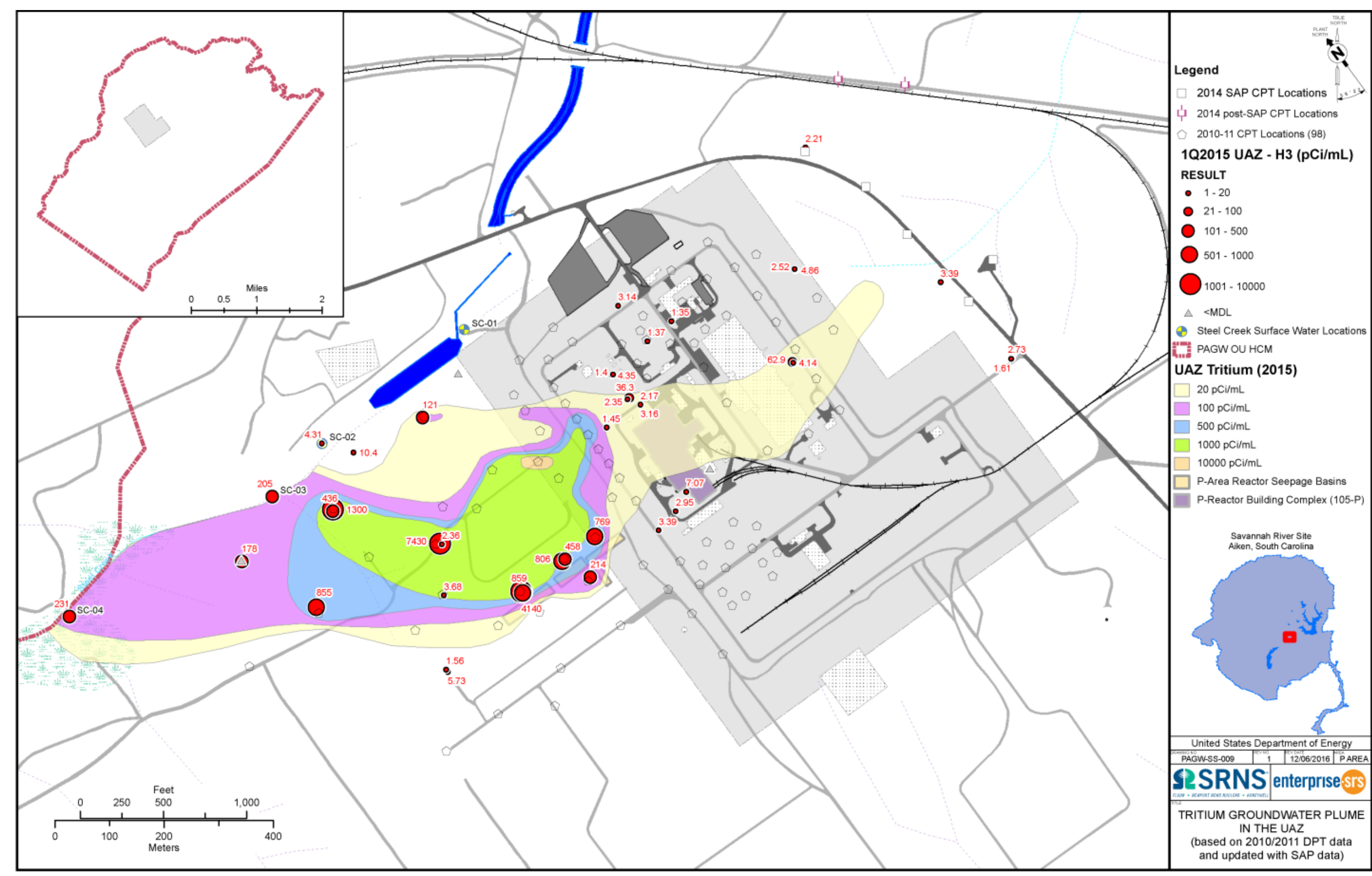


River Site 


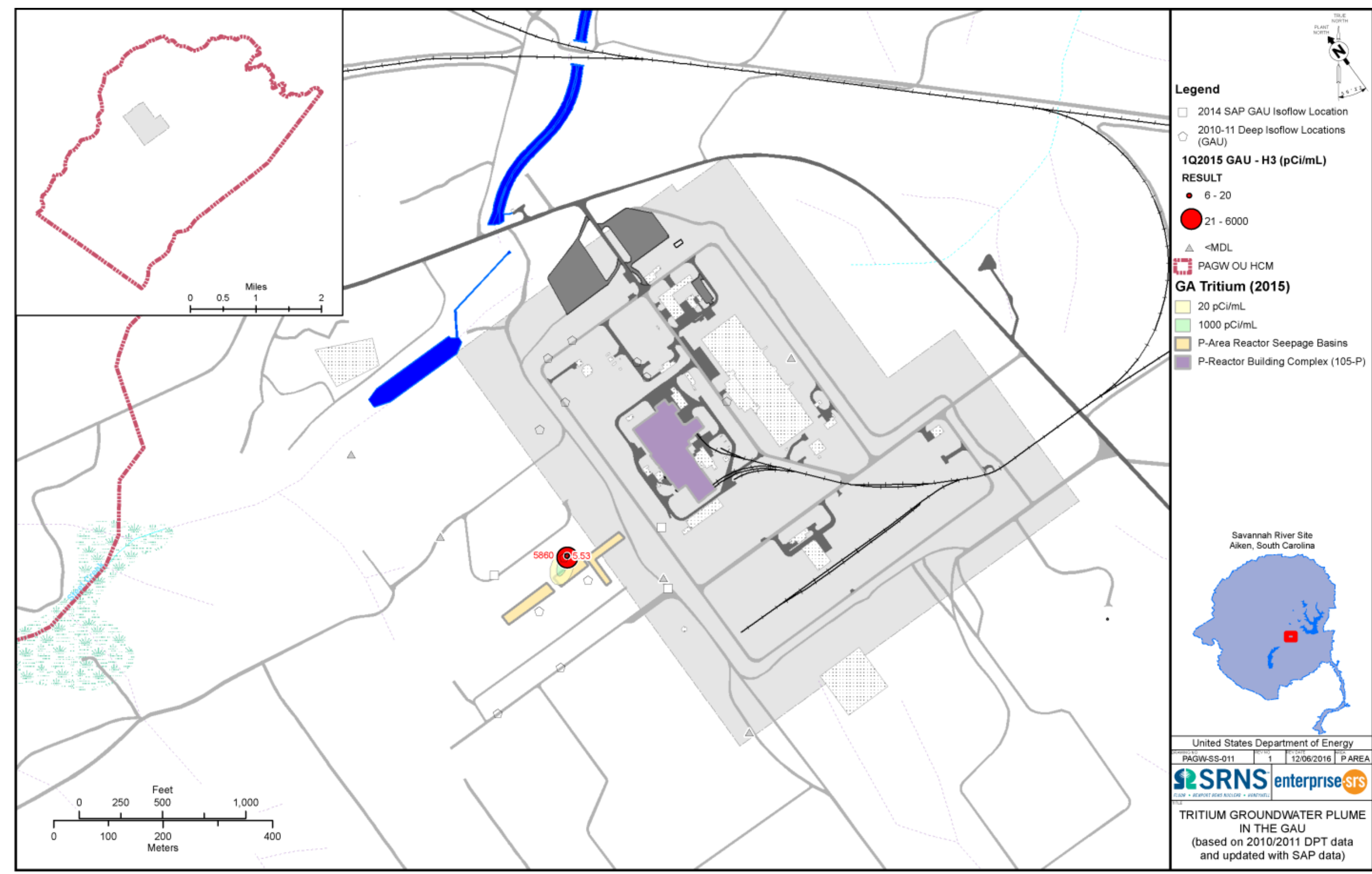




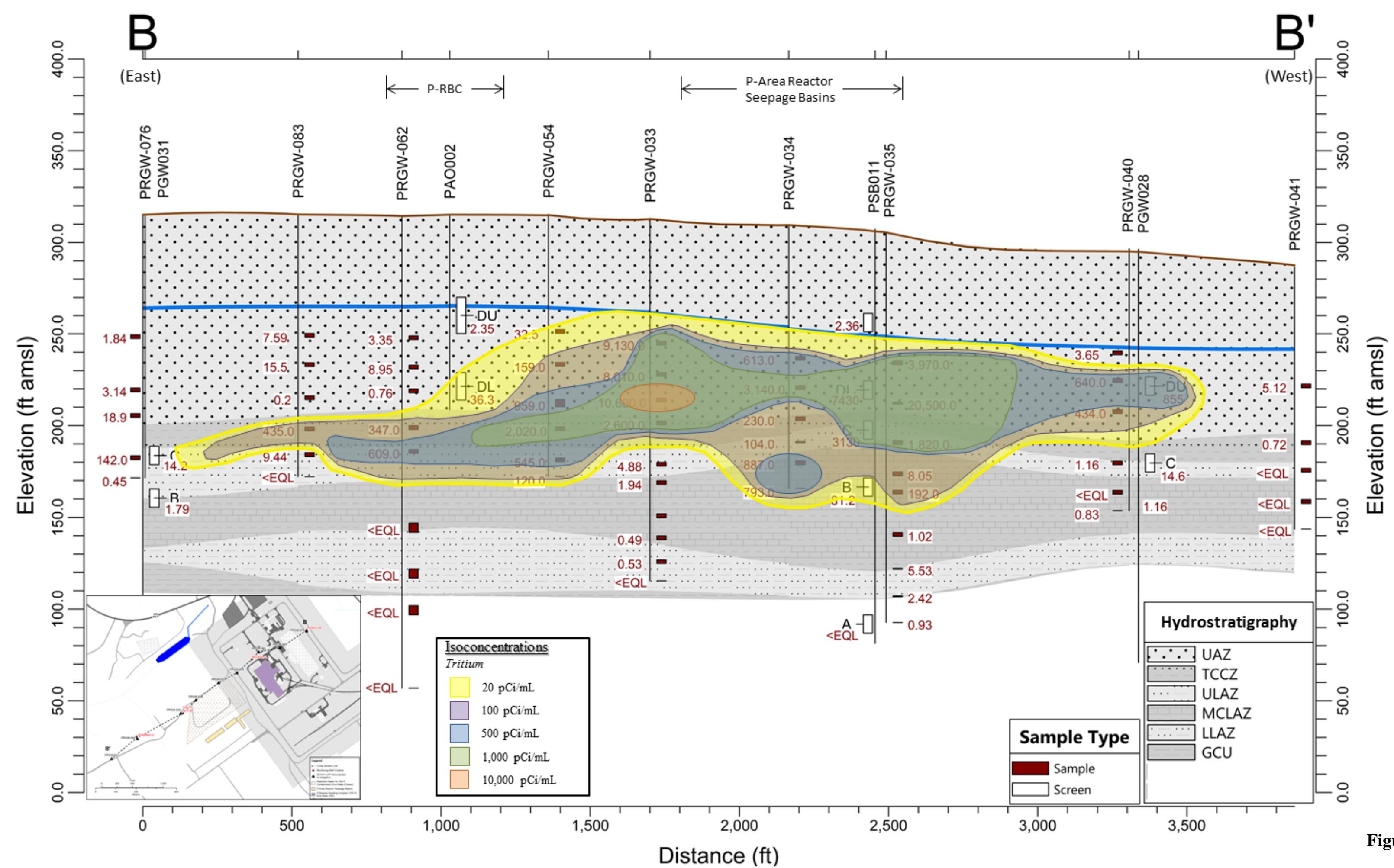

Figure 3. Cross Section B-B of Tritium Groundwater Plume from East of $P$ Area West towards Steel Creek 
River Site

This page intentionally left blank. 


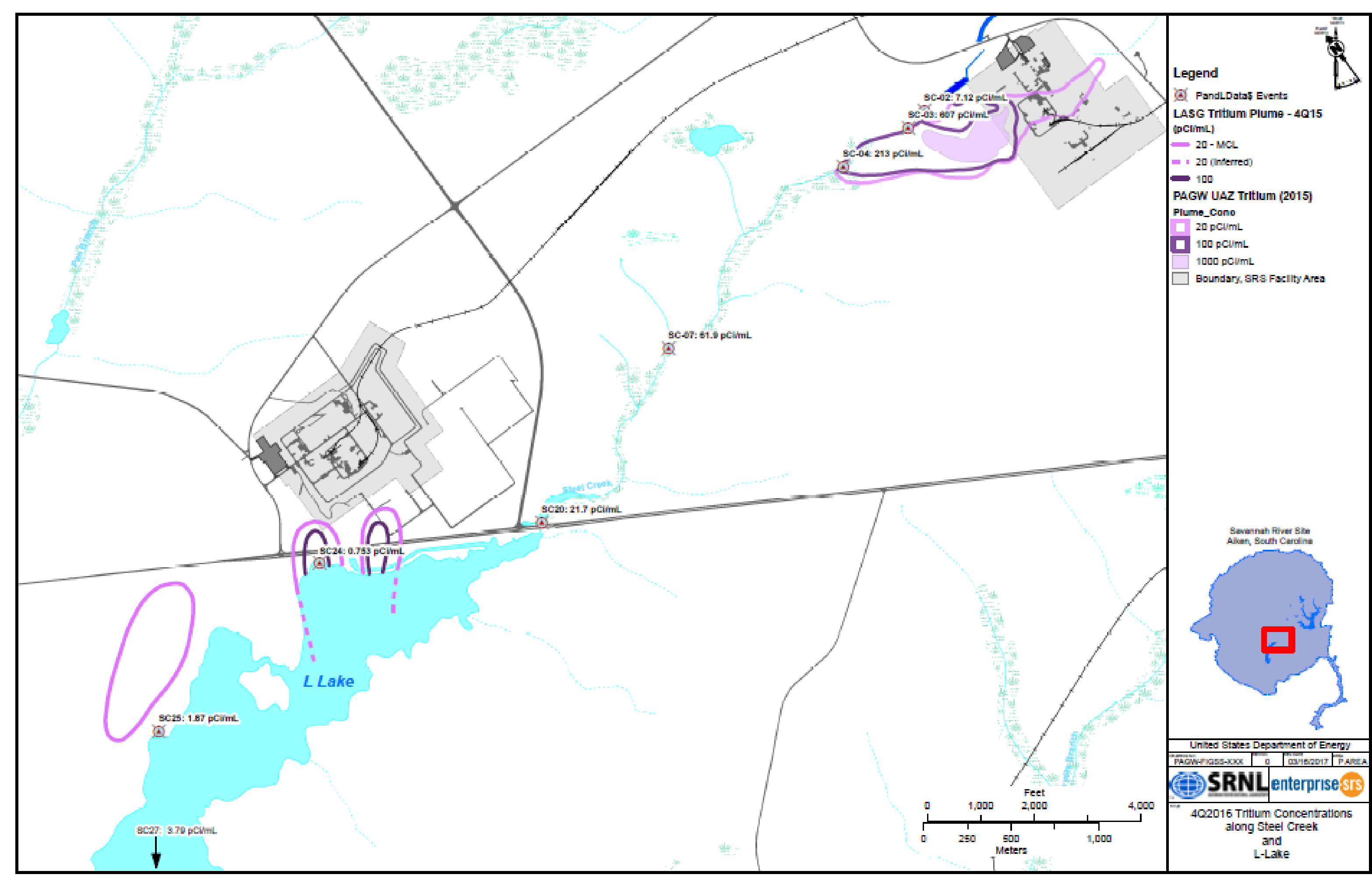

Figure 4. PAGW and LASG Tritium Plumes and Steel Creek Surface Wate Concentrations 


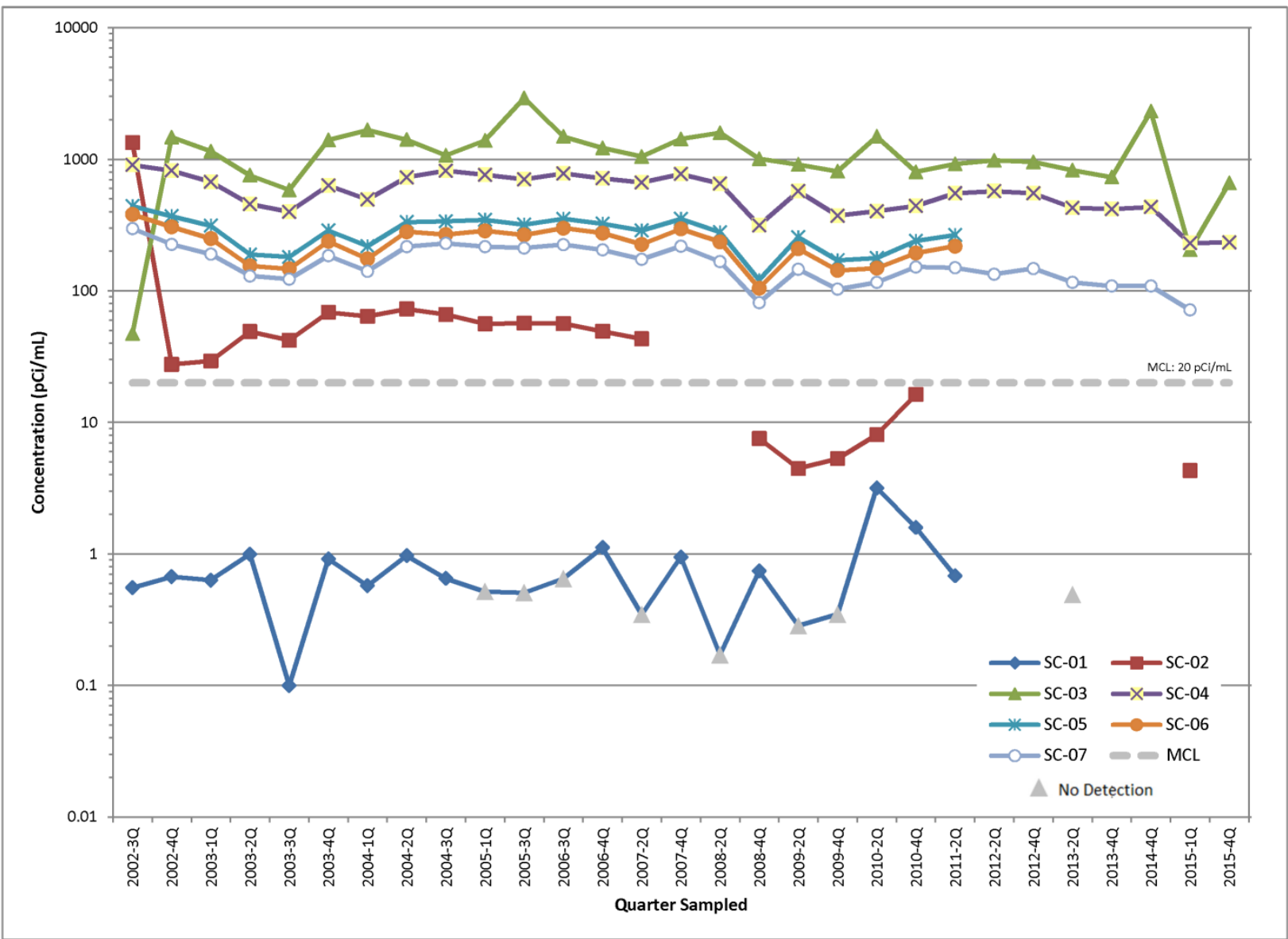

Figure 5. Time versus Concentration Plot for Tritium in Surface Water 
Technical/Administrative Options for Managing Tritium

ERD-EN-2017-0034

MCL Exceedances in P-Area Groundwater and Steel Creek

Revision 0

Savannah River Site

April 2017

Page 20 of 22

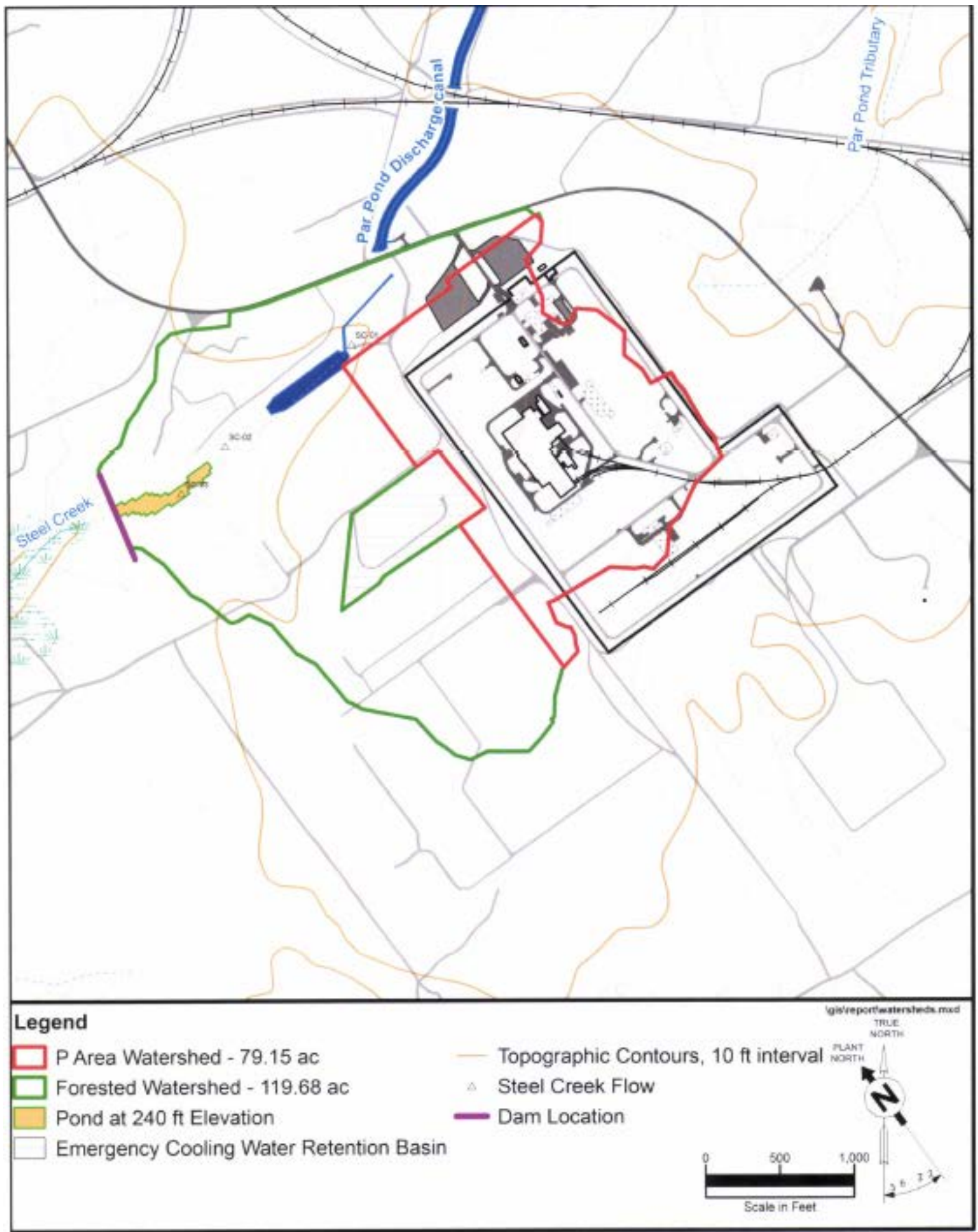

Figure 6. Steel Creek Surface Water Collection Pond and Watersheds 


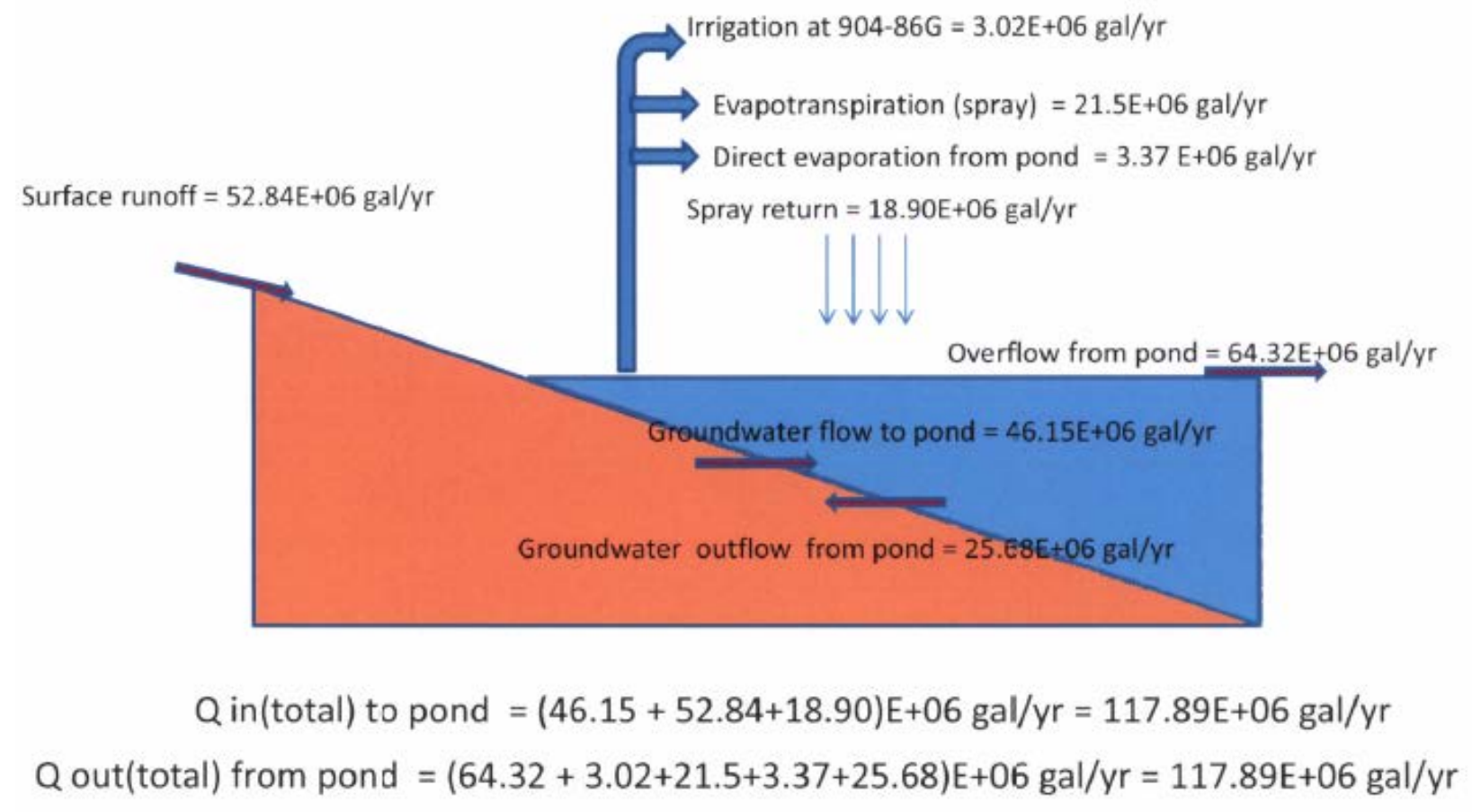

Figure 7. Phytoirrigation from Collection Pond Average Annual Water Balance 
This page intentionally left blank. 